\title{
CANDIDO: Uma LeITURa Paródica de Candide
}

\section{Maria Gloria Cusumano Mazzi ${ }^{1}$}

RESUMO: O presente artigo estuda a leitura paródica que Leonardo Sciascia (1921-1989) faz de Voltaire (1694-1778) mediante o cotejo das obras: o hipertexto Candido ovvero Un sogno fatto in Sicilia (1977) e o hipotexto Candide ou l'optimisme (1759). Apresenta ainda outra possibilidade de leitura, ou seja, Candido como metáfora da própria intertextualidade.

PALAVRAS-CHAVE: literatura comparada; intertextualidade; paródia; metáfora. 
ABSTRACT: L'articolo che qui si presenta è uno studio sulla lettura parodica che Leonardo Sciascia (1921-1989) fa di Voltaire (1694-1778) attraverso il confronto delle opere: l'ipertesto Candido ovvero Un sogno fatto in Sicilia (1977) e l'ipotesto Candide ou l'optimisme (1759). Presenta inoltre un'altra possibilità di lettura, cioè, Candido come metafora della propria intertestualità.

PAROLE CHIAVE: letteratura comparata; intertestualità; parodia; metafora.

ABSTRACT: This present study is about the parody-reading that Leonardo Sciascia (1921-1989) makes of Voltaire (1694-1778) through a comparative investigation of the works Candido ovvero Un sogno fatto in Sicilia (1977) and Candide ou l'optimisme (1759).

KEYWORDS: comparative literature; intertextuality; parody. 
Dice Montesquieu che "un'opera originale ne fa quasi sempre nascere cinque o seicento altre, queste servendosi della prima all'incirca come i geometri si servono delle loro formule". Non so se il Candide sia servito da formula a cinque o seicento altri libri. Credo di no, purtroppo: ché ci saremmo annoiati di meno, su tanta letteratura. Comunque, che questo mio racconto sia il primo o il seicentesimo, di quella formula ho tentato di servirmi. Ma mi pare di non avercela fatta, e che questo libro somigli agli altri miei. Quella velocità e leggerezza non è più possibile ritrovarle: neppure da me, che credo di non avere mai annoiato il lettore. Se non il risultato, valga dunque l'intenzione: ho cercato di essere veloce, di essere leggero. Ma greve è il nostro tempo, assai greve.

(Leonardo Sciascia, 1990)

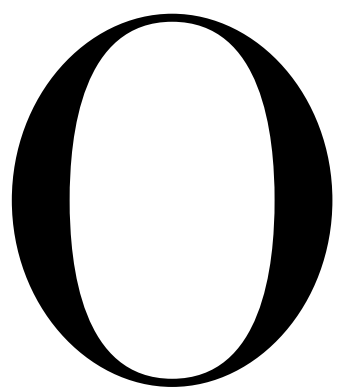

mais iluminista dos escritores italianos contemporâneos, Leonardo Sciascia (1921-89) foi assíduo leitor dos franceses: Diderot, D’Alembert, Montesquieu, Stendhal, Victor Hugo e, principalmente, Voltaire, a ponto de ser conhecido entre os críticos italianos como o Voltaire da Sicília.

Sciascia lê Candide ou L'optimisme (1759) e o reescreve em Candido ovvero Un sogno fatto in Sicilia (1977), indo de encontro à opinião de um personagem de um outro romance seu, Todo Modo, escrito três anos antes, que falava da impossibilidade de reescrever o livro de Voltaire. Num processo de autotextualidade, Sciascia retoma parte de um diálogo entre o narrador-personagem e um certo dom Gaetano, em que este comenta as palavras do escritor Italo Calvino sobre Voltaire, escritas na introdução da versão italiana de Candide (CALVINO, 1995, p. 9): 
$\grave{E}$ stato detto che il razionalismo di Voltaire ha uno sfondo teologico incommensurabile all'uomo quanto quello di Pascal. Io [continua dom Gaetano] direi anche che il candore di Candide vale esattamente quanto lo spavento di Pascal, se non è addirittura la stessa cosa. [...]. "Il faut cultiver notre jardin...” Impossibile: c'è stato un grande e definitivo esproprio. E forse si possono oggi riscrivere tutti $i$ libri che sono stati scritti; e altro anzi non si fa, riaprendoli con chiavi false, grimaldelli e, mi consenta un doppiosenso banale ma pertinente, piedi di porco. Tutti. Tranne Candide (SCIASCIA, 1974, p. 105-6, grifamos o intertexto de Calvino).

O personagem falava da exceção (tranne) feita à reescritura de Candide por causa de uma grande e definitiva expropriação que devastara os jardins, isto é, enfraquecera a ideologia burguesa que havia dado sustentação ao projeto do personagem Candide, que apesar de todas as desventuras, explica dom Gaetano, "trovava finalmente un proprio giardino da coltivare" (SCIASCIA, 1974, p. 106).

Os acontecimentos italianos fizeram o escritor mudar de ideia e reescrever um Candide italiano, realizando assim um frustrado projeto de Dostoiévski, que, segundo Bakhtin, planejava escrever um Candide russo. Como se sabe, Bakthin viu nos contos filosóficos de Voltaire a presença da tradição menipéia e da carnavalização. Voltaire era, para Dostoievski, o "Luciano da Antiguidade" (BAKHTIN, 1970, p. 194).

O modelo voltairiano é usado por Sciascia em Candido como chave de leitura da sociedade italiana, em que dominam (segundo o autor) dois universais ideológico-políticos: o catolicismo e o comunismo, muitas vezes confluentes ou até refletidos mutuamente, com todas as suas contradições, incongruências e absurdos. Isso tudo é apresentado num conto rápido e leve nas intenções, mas que resulta meticuloso e aderente à crônica terrível do pós-guerra. "Se non il risultato valga dunque l'intenzione: ho cercato di essere veloce, di essere leggero. Ma greve è il nostro tempo, assai greve" (SCIASCIA, 1990, p. 133).

Candido é a reescritura paródica de Candide, paródia entendida como canto paralelo e não como contra-canto, porque em Sciascia ela se constitui em homenagem a Voltaire, embora assinale uma diferença irônica e crítica em relação ao texto pa- 
rodiado. Parodiar não implica necessariamente na ausência de seriedade. Longe de depreciar seu modelo, a transformação paródica de Sciascia contribui, ao contrário, para sua valorização.

Em geral, só as grandes obras são objeto da paródia porque provocam uma admiração que leva o parodista a rivalizar com elas. Grandes obras suscitam também a vontade de relativizar sua glória (a paródia opera com frequência uma espécie de dessacralização). Elas permitem igualmente a seu parodista compartilhar dessa glória, uma vez que reescrever um texto sobre um texto célebre pode significar a participação em sua celebridade. Naturalmente, isto ocorre quando o novo texto é bem escrito. Sciascia considera a celebridade de Candide ao referir-se a ela como un'opera originale, conforme veremos mais adiante. E mais, o próprio funcionamento da paródia exige que a obra parodiada seja reconhecível sob o hipertexto, isto é, seja suficientemente (re)conhecida para ser identificada pelo leitor. Essa necessidade de identificação explica por que frases curtas como os provérbios, citações célebres, slogans são constantemente parodiados. Genette escreve: "Tout énoncé bref, notoire et caractéristique est pour ainsi dire naturellement voué à la parodie" (1982, p. 44).

A paródia, como dissemos, requer um leitor competente que reconheça, na leitura da obra, o texto a que ela se refere, isto é, que parodie. Em Candido, Sciascia conduz abertamente a uma leitura dupla por meio dos seguintes recursos paratextuais (GENETTE, 1982):

1 - A capa do livro de Sciascia traz como ilustração a figura do busto de Voltaire em idade madura (sábio, talvez), dominando o espaço central de uma estante com alguns livros simetricamente distribuídos nas suas laterais. Entre os livros, abaixo do retrato, há duas penas entrecruzadas que podem simbolizar as duas escrituras e o próprio processo da intertextualidade. $\mathrm{E}$, ainda, a moldura que ornamenta o quadro parece mais adequada para espelhos, sugerindo uma leitura paródica da obra, uma vez que a paródia também apresenta as imagens "originais" invertidas. Ao leitor desinformado sobre a ilustração, a contracapa explica que se trata de uma gravura de Henry Keen: "Voltaire: incisione di Henry Keen, 1926" (SCIASCIA, 1990).

2- O título e o subtítulo da obra, Candido ovvero Un sogno fatto in Sicília, constituem elementos altamente polifônicos. O substantivo optimisme, que em Voltaire já é 
irônico, na medida em que toda a filosofia referente a ele é desacreditada, em Sciascia é substituido por un sogno [sonhado na Sicília] que pode significar a própria ficção, ou a impossibilidade de ser cândido no contexto siciliano apresentado por ele.

3- E, principalmente, há uma nota explicativa no final do livro (usada como epígrafe deste artigo) em que o autor adverte seu leitor que partiu da formula originale - il Candide para criar o seu Candido.

Em síntese, podemos dizer que o livro de Sciascia narra a vida do personagem Candido Munafò em meio às mudanças político-sociais da Itália do pós-guerra. $\mathrm{O}$ narrador fala da formação do protagonista com seu preceptor dom Antonio, de suas experiências amorosas (primeiro com Paola e depois com sua prima Francesca), sua relação com a política e a religião, até chegar à maturidade (34 anos), quando Candido decide deixar a Itália para morar na França de Voltaire. Na primeira parte de Candido, os fatos se desenrolam com velocidade e, por meio deles e do próprio desenvolvimento da narração, emerge o juízo de Sciascia sobre os acontecimentos. Esse feliz ritmo narrativo, que conta a infância e a adolescência de Candido, enfraquece na segunda parte do conto (após a viagem religiosa que o protagonista faz a Lourdes), perdendo a leveza e a naturalidade porque agora parece que a ideologia e o moralismo do autor querem impor-se.

Em Sciascia, a crise da ideologia, de um racionalismo entendido como visão realista-historicista do mundo, não leva à renúncia da Razão. Esta se reduz a método de análise, isto é, a razão é uma atitude crítica diante da realidade. Daí o gosto pelo conte philosophique do século XVIII, que serve de modelo de confronto com a história, ao mesmo tempo em que assinala um desejo de retorno a uma época em que natureza e história, sociedade e indivíduo eram racionalmente recomponíveis. O conte philosophique é um gênero que apresenta uma dificuldade peculiar: parece fácil quando, na verdade, requer um raro talento (como o de Voltaire), que seja capaz de exprimir grandes lições de filosofia por meio de pequenas e rápidas "chamadas" de fantasia, ou por meio dos próprios acontecimentos narrados. É preciso ser filósofo sem demonstrá-lo. Sciascia sabe que não tem l'esprit de Voltaire e, além do mais, vivemos tempos difíceis, ele diz.

O racionalismo sciasciano como método de análise significa, nas palavras do crí- 
tico Romano Luperini, que: "la critica alla storia e al mondo deve scaturire quindi dalle cose stesse e in questo caso [de Candido] dal cozzo tra la naturale tendenza alla vita e alla felicità di un giovane e le norme stupide e oppressive di un sistema sociale apparentemente razionale, in realtà assurdo" (1981, p. 767).

No interior da narrativa sciasciana, Voltaire é citado em cinco momentos significativos e sua obra em questão, parodiada em outros três.

O primeiro aparece na segunda página do livro, quando o personagem Candido é apresentado como filho do advogado Francesco Maria Munafò, que, apesar da coincidência dos nomes, nunca ouviu falar de um certo François-Marie Arouet (Voltaire) e sua obra. O narrador conta, num tom irônico e com bastante sutileza, que:

l'esistenza di un libro intitolato a quel nome, di un personaggio che vagava nelle guerre tra avari e bulgari, tra gesuiti e regno di Spagna, era perfettamene ignota all'avocato Francesco Maria Munafò; nonché l'esistenza di un Francesco Maria Arouet, che di quel personaggio era stato creatore [...]. Come poi entrambi [os pais de Candido] avessero attraversato ginnasio, liceo e università senza mai sentire parlare di Voltaire e di Candido, non è da stupirsene: capita ancora. (SCIASCIA, 1990, p. 10).

O narrador critica a ignorância dos italianos de classe média, que, mesmo tendo frequentado a universidade, não estudaram um autor da importância de Voltaire, e aproveita para orientar o leitor desinformado. Por meio da ironia, o narrador avalia e julga a carência de certos valores da sociedade. Daí a ironia requerer um leitor com uma tripla competência: a linguística, para entender o que está implícito; a retórica ou genérica, referente às regras para perceber o desvio estético e, enfim, a competência ideológica, que diz respeito ao conhecimento dos valores sociais.

O segundo momento se verifica no título do capítulo décimo primeiro em que é retomada a fórmula da conclusão final do personagem Candide - "Cela est bien dit, répondit Candide, mais il faut cultiver notre jardin" (VOLTAIRE, 
1972, p.115) - parodiando-a: “Del tentativo che l'ex arciprete fece di dedicarsi a coltivare il proprio orto $e$ Candido le proprie terre; $e$ delle delusioni che ne ebbero" (SCIASCIA, 1990, p. 58, grifamos).

Os personagens sciascianos dom Antonio e Candido procuram colocar em prática (literalmente) o ensinamento de Candide, que fala de uma regeneração do homem mediante a natureza e o trabalho, mas sem sucesso.

Tendo sido expulso da Igreja, dom Antonio muda-se para sua antiga casa no campo com a intenção de cuidar das hortas abandonadas, plantando nelas o suficiente para o próprio sustento. Buscando na memória os ensinamentos que o pai camponês lhe deixara, o ex-vigário limpa o terreno, ara, aduba, semeia, enfim, faz o que pode pela terra, mas, diz o narrador: "o che la memoria gli falisse o che la terra, l'aria, la vicenda della pioggia e del sole, il giro delle stagioni fossero mutati, tutto gli veniva su stentato, malato" (SCIASCIA, 1990, p. 59).

Quanto a Candido, entusiasmado com a iniciativa de seu preceptor, ele toma a decisão de recensear suas propriedades rurais para, em seguida, trabalhar diretamente em uma delas. Desconsiderando a hostilidade dos camponeses para com ele, Candido passa muitas horas adubando a terra. O narrador comenta o resultado dessa experiência num tom irônico: "Si era scelto un pezzo di terra vicino a una sorgente, lo aveva ben dissodato e concimato; tanto bene concimato che quel che poi vi seminò venne su come bruciato" (SCIASCIA, 1990, p.60, grifamos).

Vale ressaltar que, na versão italiana de Candide (1995), de Piero Biancone, com introdução de Italo Calvino, o vocábulo jardin é traduzido por orto e permanece hoje na expressão coltivare il proprio orto com a mesma conotação que tem entre nós, ou seja, a de "cuidar dos próprios afazeres". Porém, em francês a palavra jardin tem dois significados: "terrain où l'on cultive des végétaux utiles (potager, verger) ou d'agrement (parterre de fleurs, bosquets)" (PETIT LAROUSSE, 1982). Certamente para Voltaire, jardin se refere à horta que pressupõe uma atividade de trabalho (arar, plantar e colher os frutos da terra) e não a jardim que remete à ideia de lazer.

$\mathrm{O}$ terceiro acontece quando dom Antonio discorre sobre o seu passado de 
padre e explica suas dificuldades de liberar-se daqueles anos terríveis de preconceito. Ele diz a Candido:

$\grave{E}$ stata una lunga malattia; ed ora sono in convalescenza. È facile far cadere uno dopo l'altro, come nel barracone del tiro al bersaglio, tutti i dogmi, $i$ simulacri, e $i$ simboli che sono stati parte della tua vita: direi che basta la piccola carabina del Dizionario di Voltaire; se l'occhio non è appannato. (SCIASCIA, 1990, p.70, grifo do autor).

O comentário de dom Antonio faz referência à filosofia de Voltaire, cuja "carabina" da razão, da lucidez, do bom senso, é capaz de derrubar os antigos dogmas, sendo necessário apenas manter os olhos bem abertos.

O Dicionário Filosófico de Voltaire, escrito em 1764, com enorme sucesso na época, tinha a intenção explícita de ridicularizar o fanatismo religioso (daí ser citado pelo ex-vigário). Como o maior porta-voz do anticlericalismo francês, Voltaire combateu com veemência os fanáticos e os patifes, suas hipócritas declamações e seus miseráveis sofismas. $\mathrm{O}$ escritor apelou publicamente aos intelectuais e iluministas de seu tempo para que se unissem a ele nessa luta, impedindo que homens inteligentes como eles fossem dominados por mentes medíocres. Todas as suas cartas (livros, panfletos, apelos) terminavam com a frase célebre écrasez l'infâme numa referência explícita de combate à Igreja.

O quarto momento ocorre na passagem em que Candido encontra Paola, seu primeiro amor, e esta deixa cair seu lencinho para que ele o apanhe, repetindo o gesto da personagem Cunégonde, que em Voltaire parodia os romances folhetinescos da época:

Cunégonde laissa tomber son mouchoir, Candide le ramassa; elle lui prit innocemment la main; le jeune homme baisa innocemment la main de la jeune demoiselle avec une vivacité, une sensibilité, une grâce toute particulière; leurs bouches se rencontrèrent, leurs yeux s'enflammerènt, leurs genoux tremblèrent, leurs mains s'égarèrent. (VOLTAIRE, 1972, p. 19).

O narrador sciasciano cita a passagem de Candide literalmente e entre aspas (da 
versão italiana), invertendo criticamente a cena final:

Candide lo raccolse. Lei gli prese innocentemente la mano, Candide innocentemente baciò la mano di lei con una vivacità, una sensibilità e una grazia particolarissime; le bocche si incontrarono, gli occhi si accesero, le ginocchia tremarono, le mani si smarrirono.

A differenza del suo omonimo, (...), Candido ebbe quel giorno un lungo, pieno e quieto godimento. Godimento lungamente, pienamente e quietamente condiviso da Paola (SCIASCIA, 1990, p.72, grifamos).

O Candido italiano, ao contrário do francês, não recebe nenhuma punição (sua expulsão do castelo) pelo beijo. Conquista sua Cunégonde/Paola e consuma completamente o ato sexual, conforme demonstram os advérbios do enunciado.

Candide é expulso do castelo pelo tio, porque o beijo em Cunegonde é um ato que transgride a hierarquia social imposta pela classe dominante, a aristocracia, representada pela baronesinha, porquanto ele tem origem duvidosa (filho de uma nobre e um plebeu). Candide representa a classe em ascensão, a burguesia consolidada com a Revolução Francesa (1789), que teve em Voltaire seu maior precursor.

Candido, por sua vez, que pertence à média burguesia italiana, mas almeja viver conforme os ideais socialistas, filia-se ao Partido Comunista Italiano que, numa atitude hipócrita pequeno-burguesa, desaprova sua união com a empregada da casa, Paola, embora tivesse tolerado o relacionamento anterior que ela mantinha com o ex-patrão, o velho general Arturo, avô do protagonista. Esse será um dos motivos que o Partido vai alegar contra a conduta moral de Candido para mantê-lo afastado dos companheiros.

A quinta e última referência explícita ao escritor francês aparece no final do livro, quando Candido, Francesca e dom Antonio, em Paris, diante da estátua de Voltaire, trocam algumas palavras sobre ele. $\mathrm{O}$ significado delas será discutido mais adiante.

Candide de Voltaire é uma obra polifônica, carnavalizada e paródica (FACHIN, 1995): paródia (contracanto) do romance sentimental e folhetinesco da época e, principalmente, paródia das filosofias alemães dominantes - a Metafísica de Leibniz (1646- 
1716) e a Cosmologia de Wolff (1679-1754) - com as desastrosas consequências que trazem para a vida. De fato, não havia nada mais ilusório e falso do que pensar que se vivia "no melhor dos mundos possíveis". Por meio da viagem, princípio organizador do conto, o protagonista é abandonado à existência e experimenta o mundo com todas as suas imprevisíveis reviravoltas. Estamos no século XVIII que é essencialmente prático e busca o conhecimento universal. Século em que predominam as narrativas de caráter moralista, em torno de uma ideia, como o conto filosófico, gênero do qual Voltaire é mestre.

O conto filosófico ou conto de ideias, como o próprio nome indica, implica uma visão filosófica da existência, uma vez que, por meio dele, o escritor apresenta "a síntese generalizada das observações que a vida lhe permitiu fazer acerca dos homens e do mundo" (MOISÉS, 1967, p. 114).

Os personagens, a história e os procedimentos narrativos servem como instrumento de concretização da ideia a ser transmitida, de modo que ela predomina sobre os demais componentes. A ideia não é estabelecida a priori como em geral acontece nos contos planfletários, mas é identificada com os personagens e as ações, surgindo no fluxo da história.

Enquanto narrativa de aprendizagem, o conto filosófico apresenta um protagonista que deve ser portador de pureza ou inocência, porque ele será deslocado repentinamente para uma outra realidade totalmente estranha, mas que terá de assimilar a todo custo. É por isso que, na abertura do conto voltairiano, Candide é expulso do castelo de Thunder-ten-tronckh "à grands coups de pied dans le derrière" (VOLTAIRE, 1972, p.17), após ter sido flagrado beijando a baronesinha Cunégonde (paródia do pecado original), e passa a enfrentar todo tipo de calamidades que atingem também os outros personagens, o castelo, a Westphalie e o mundo inteiro. O castelo representa não só a Europa soberana que se considera autossuficiente, mas, principalmente, a Monarquia que Voltaire quer combater a todo custo. Somente fora dele, Candide terá a oportunidade de conhecer o "outro" e aprender com o diverso. Assim, logo no início da narrativa, o protagonista é apresentado como "un jeune garçon à qui la nature avait donné les moeurs les plus douces. Sa physionomie annonçait son âme. Il avait le jugement assez droit, avec l'esprit le plus simple; c'est, je crois, pour cette raison qu'on le nom- 
mait Candide" (VOLTAIRE, 1972, p. 17).

A motivação psicológica, decorrente da própria natureza de Candide, determina seu comportamento, sobretudo, em relação a dois personagens: Pangloss e Cunégonde. Daí a crença, sem reservas, na tese de seu preceptor Pangloss, apresentado justamente como: "l'oracle de la maison que enseignait la métaphysico-théologo-cosmolonigologie et le petit Candide écoutait ses leçons avec toute la bonne foi de son âge et de son caractere" (VOLTAIRE, 1972, p. 17).

Quanto à filha do barão, a senhorita Cunégonde, "âgée de dix-sept ans, était haute en couleurs, fraîche, grasse, appétissante", é para Candide "extrêmement belle quoiqu'il ne prît jamais la hardiesse de le lui dire” (VOLTAIRE, 1972, p. 19).

Cunégonde será a presença recorrente no encadeamento do conto. Assim que é expulso do castelo, Candide viaja pelo mundo "n'oubliant jamais Mlle Cunégonde (VOLTAIRE, 1972, p. 25), esperando "toujours revoir Mlle Cunégondei" (VOLTAIRE, 1972, p. 77). O nome de Cunégonde é repetido muitas outras vezes, juntamente com as fórmulas características do otimismo: "le meilleur des mondes; la raison suffisante; les effets et les causes", num ritmo de ladainha, cujo efeito irônico produz ótimos resultados.

A viagem em Candide é metáfora do conhecimento porque, por meio dela se dão a evolução e a aprendizagem do protagonista, que aprende na prática que a tese do otimismo é falsa. Ao conhecer o país do Eldorado, tão diferente de Westphalie, Candide conclui que "il est certain qu'il faut voyager" (VOLTAIRE, 1972, p. 68). Da Westphalie até o país do Eldorado, o percurso de Candide constitui a prova da existência do mal; daí ele ser marcado pela constante fuga. Até aqui, sua aprendizagem é lenta e difícil. Estando fora do castelo, ele compreende que a filosofia de Pangloss não faz mais sentido e começa a questionar todo o sistema de seu antigo mestre. No capítulo IV, ao saber da morte de Cunégonde, ele diz: "Ah! meilleur des mondes, où êtes-vous?" (VOLTAIRE, 1972, p. 27).

A necessidade de renunciar à filosofia de Pangloss só aparece no capítulo XIX, quando Candide conhece as misérias da escravidão e passa a definir o otimismo como "la rage de soutenir que tout est bien quand on est mal" (VOLTAIRE, 1972, p.74). A partir do episódio do Eldorado (cap. XVIII), situado no meio do conto, Candide e 
seu fiel criado, Cacambo, começam a viagem de volta à Europa: agora não precisam mais fugir, e a evolução de Candide é mais rápida. Eles seguem sempre à procura de Cunégonde, continuando as (des)aventuras até encontrar o Jardim da Propôntida, onde vão cultivar as próprias terras. Vale notar que Candide sai do espaço perfeito e fechado do castelo para o espaço aberto representado pelo resto do mundo, mas, no final, se refugia num espaço delimitado do jardin. Voltaire ensina que, à maneira da horta de Candide, a nossa terra é uma terra de limitações. Do capítulo XXIV em diante, Candide já não tem nehuma ilusão a respeito do bem: "tout n'est qu'illusion et calamite" (VOLTAIRE, 1972, p. 92) e, na conclusão do conto (cap. XXX), Candide é todo Voltaire: "il y a horriblement de mal sur la terre" (VOLTAIRE, 1972, p. 112).

No segundo momento do conto, Candide conhece Martin, a contraposição da filosofia de Pangloss, segundo a qual o mal existe e nada pode ser feito para combatê-lo. Agora a crítica de Voltaire se dirige ao maniqueísta Martin, a antítese do otimismo. No entanto, Candide também rejeita o pessimismo deste último. Então, decide pedir conselho a um dervixe e a um ancião turco: o primeiro diz que é preciso calar-se diante do mal, isto é, não perder tempo com a metafísica (ou com tudo o que transcenda a observação prática e a experiência, que busque verdades absolutas). O segundo ensina que o trabalho afasta o homem dos três males do mundo: o tédio, o vício e a necessidade.

Candide, agora amadurecido, reflete sobre todos os acontecimentos e conclui que é inútil procurar uma explicação metafísica do mal como querem o otimista Pangloss e o pessimista Martin, porque esse mal é subjetivo, indefinido e fruto das paixões. Ora, o mal existe e decorre das paixões humanas, mas viver sem elas pode trazer o tédio (como bem assinala a personagem da velha no cap. XXX), a doença mais temida no século XVIII. Assim, enquanto Pangloss insiste em afirmar que "tous les événements sont enchaînés dans le meilleur des mondes possibles" (VOLTAIRE, 1972, p. 115), e Martin em dizer que trabalhar sem filosofar é "le seul moyen de rendre la vie supportable" (VOLTAIRE, 1972, p. 114), Candide propõe um meio-termo: plantar e colher frutos na pequena chácara que lhe restou, onde cada qual deve trabalhar segundo sua capacidade. Em síntese, ele ensina que devemos "cultiver notre jardin" (VOLTAIRE, 1972, p. 115).

O que Voltaire propõe com a célebre frase, que tanta polêmica causou, é um modo 
de viver, uma sabedoria prática para além de tantas teorias, capaz de superar o trágico contraste entre a aspiração à felicidade e a impossibilidade de conquistá-la definitivamente neste mundo. Voltaire propõe um savoir vivre do homem na sociedade. Afinal, como ele próprio escreveu numa carta endereçada a Mme de Bernières em 1722, "la grande e unica cura che si deve avere è di essere felici" (apud CAMPI, 1994, p. 11).

Dotado de um espírito crítico exacerbado, Voltaire participa das grandes discussões do século XVIII, em que tudo é questionado, o direito divino, a religião e a moral tradicional, até chegar à concepção de uma filosofia toda fundada na natureza. Fala-se de direito natural, religião natural, educação natural, e da felicidade também como um bem conquistado naturalmente pelo homem e por meio dele. Portanto, a felicidade (le bonheur) não é mais atrelada ao eterno, ao divino, ela é temporal. Sendo o homem o centro do universo, sua felicidade e bem-estar têm de ser imediatos. A democracia, conquanto burguesa, se apresenta, na época, como o meio mais imediato de acabar com a monarquia e trazer um pouco de liberdade e justiça e, portanto, de felicidade.

Na filosofia otimista, Voltaire não vê apenas um mero fatalismo que desencoraja toda e qualquer atividade em nome da Providência. O otimismo é também uma das imposturas da "metafisico-teologo-cosmolonigologia", que ele sente como um ultraje ao bon sens e à racionalidade. Como se já não bastassem os horrores e as misérias existentes no mundo, essa filosofia impunha a crença absurda de negá-los. No final do conto, Candide não quer mais discutir, porque o que realmente conta agora são os fatos concretos, práticos: cuidar da própria horta como uma maneira de ser menos infeliz.

Este é o projeto inicial do Candido sciasciano: a busca da felicidade prática e imediata. Candido parece começar a partir de onde Candide parou, uma vez que para ele:

soltanto i fatti contano, soltanto i fatti debbono contare. Noi siamo quel che_facciamo. Le intenzioni, specialmente se buone, e i rimorsi, specialmente se giusti, ognuno, dentro di sé, può giocarseli come vuole, fino alla disintegrazione, alla follia. Ma un fatto è un fatto: non ha contraddizioni, non ha ambiguità, non contiene il diverso e il contrario. (SCIASCIA, 1990, p.100, grifamos).

Sartreanamente, Candido parece saber que "só os atos decidem sobre aquilo que a 
gente quis" (SARTRE, 1966, p. 71).

Porém, o contexto de Candide não é o de Candido. Este, nascido em 1943, numa típica família da média burguesia siciliana, tem uma visão de mundo definida autodidaticamente a partir de desordenadas, mas abundantes leituras, e de experiências vividas com alegre curiosidade. Aqui, a viagem consiste também em deslocamentos geográficos, mas ela se realiza, principalmente, por meio de viagens intertextuais, isto é, da escritura e da leitura. Seguindo a moral do empenho prático e responsável, Candido apresenta uma conduta que, para ele, está acima do bem e do mal: "[...] era refrattario all'idea che ci fossero peccati al di fuori del mentire e del volere la sofferenza e l'umiliazione degli altri' (SCIASCIA, 1990, p. 64).

Ele é cândido no sentido de puro, sincero, verdadeiro, mas não ingênuo, desamparado e nem desprovido de densidade psicológica como seu homônimo. Na verdade, Candido tem vida própria, sendo um alegre desmascarador das filosofias correntes. Aplicando coerentemente suas ideias, ele é logo considerado un piccolo mostro pelas pessoas com as quais convive, causando direta, ou indiretamente, grandes mudanças por onde passa. Assim, após seu nascimento, a primeira a mudar é sua mãe que, segundo o marido e as amigas, se transforma em un'altra, abandonando a família e partindo para a América com o capitão das tropas aliadas. Aos cinco anos, Candido leva o pai ao suicídio, ao repetir com naturalidade, uma conversa sigilosa dele (um advogado medíocre) com um cliente assassino. Sempre indiferente aos acontecimentos à sua volta, o narrador explica que: "[...] Candido non sentiva la più lieve puntura dal nido di spine in cui si trovava. Pareva potesse fare felicemente a meno di una madre e di un padre [...]" (SCIASCIA, 1990, p. 24). E, ainda, que "Candido non aveva alcun culto per il padre morto, non domandava notizie della madre viva, non era affezionato al nonno e se ne infischiava anche di lei" [Concetta, sua babá] (SCIASCIA, 1990, p. 36).

O estranho comportamento de Candido leva seu avô a contatar um preceptor, dom Antonio Lepanto, para auxiliar na educação do menino. Dom Antonio, personagem oposto a Pangloss, é um vigário e psicólogo que procura conciliar a doutrina de Cristo com as teorias de Freud e

era considerato, e si considerava, moderno. Si applicava molto alla psi- 
cologia; ma nascondendo in questa parola l'altra che bisognava pronunciare allora cautamente e con molte riserve: psicanalisi. Aveva anzi scritto un trattato di psicologia morale, e cioè di psicanalisi [...]. Ma teologicamente parlando, la figura del diacono aveva contorni così incerti, così indefiniti... (SCIASCIA, 1990, p. 38, grifo do autor).

Candido fica entusiasmado com a ideia de conviver com dom Antonio porque: " $L o$ divertiva molto lo scoprire poco a poco, un colloquio dopo l'altro, com'era fatto un prete: quest'uomo misterioso [...] che faceva diventare l'ostia corpo di Cristo e otteneva che un morto salisse dal purgatorio al paradiso [...] (poteri di cui era bestemmia dubitare; ma Candido ne dubitava)" (SCIASCIA, 1990, p. 39).

Por intermédio de dom Antonio, Sciascia critica, ao mesmo tempo, a Igreja Católica, os dogmas da religião católica e as teorias da psicanálise. Logo depois das primeiras conversas, Candido descobre que o vigário tem uma espécie de ideia fixa muito complicada que quer provar a todo custo, e que consiste no seguinte: "tutti i bambini uccidono il loro padre, e qualcuno, qualche volta, anche il Padre Nostro che è nei Cieli; solo che non è una uccisione vera e propria, ma come un gioco in cui al posto delle cose ci sono i nomi e al posto dei fatti le intenzioni; un gioco, insomma, come la messa" (SCIASCIA, 1990, p. 40, grifamos).

Assim, Candido Munafò e seu Pangloss de batina, diversamente dos correspondentes voltairianos, são intelectualmente feitos um para o outro. Enquanto Candide "écoutait attentivement, et croyait innocemment" (VOLTAIRE, 1972, p. 19) em seu preceptor, o narrador sciasciano esclarece que "in realtà, era Candido che spiava e analizzava l'arciprete" (SCIASCIA, 1990, p. 39), dissuadindo-o de seus propósitos religiosos e psicanalíticos em relação a ele. $\mathrm{E}$ foi assim que Candido e dom Antonio conviveram em harmonia entre os 'Atos dos Apóstolos' e os livros de Freud e de Jung, conforme o comentário irônico do narrador: "E arrivarono così a volersi bene, al di là dei padri e del Padre Nostro" (SCIASCIA, 1990, p. 41). Candido e dom Antonio formarão os próprios pensamentos, unindo a natural e "cândida" sensibilidade de um com a cultura eclética do outro. Candido "era abituato a parlare con lui di tutto, liberamente, senza alcuna preclusione o vergogna" (SCIASCIA, 1990, p. 70). Juntos, eles 
viverão grandes, heróicas e, às vezes, cômicas aventuras. Viverão amores: Candido por Paola e depois por Francesca; dom Antonio pela Igreja, pela psicanálise e pelo Partido Comunista. Um tanto de quixotesco encontramos na batalha que os dois travam com as duas igrejas fortalecidas no pós-guerra italiano, a igreja católica e a igreja comunista, assim chamadas por Candido, que as considera imposturas. Uma luta inútil contra duas fontes de poder e corrupção inabaláveis, em que eles perdem os melhores anos de suas vidas. Apesar de tudo, no final eles conseguem sair liberi e felici, não antes de pagar o preço da humilhação, do desprezo, da ofensa intelectual e emocional. Do convívio entre eles, a transformação se dá em dom Antonio e é percebida por Candido que "lo vedeva diventare meno attivo, più stanco, più assorto, più indifferente" (SCIASCIA, 1990, p. 51).

A estrutura do hipertexto Candido, seguindo o hipotexto voltairiano, é composta por capítulos (26 contra os 30 de Candide), cujos títulos são igualmente saturados de significação, antecipando o conteúdo que será desenvolvido em cada um deles. A diferença está no fato de que enquanto em Voltaire os capítulos são fragmentários, permitindo a leitura autônoma (cada um narra uma história completa), em Sciascia eles apresentam menos independência.

Parodiando o modelo de Voltaire, a primeira parte do conto de Sciascia vai da infância à adolescência de Candido até a sua viagem de peregrinação a Lourdes (XII cap.), também situada no meio do conto como o país do Eldorado. O narrador explica que dom Antonio tinha programado a viagem religiosa para Candido "come una vaccinazione rispetto il cattolicesimo" (SCIASCIA, 1990, p. 68).

Nesta parte do conto, Sciascia critica duramente a ideologia da Igreja Católica, encerrando a discussão justamente com a viagem a Lourdes (tão utópica quanto o Eldorado), onde a conversão de Candido não se verifica, e ele inicia sua vida amorosa. Do décimo segundo capítulo em diante, dom Antonio abandona definitivamente a batina, declarando-se mais religioso do que nunca, e, junto com Candido, entra para o Partido Comunista. A partir daqui, o comportamento do ex-vigário, sua postura diante da vida, se apresenta "più umana, più diretta, più apprensiva e continua" (SCIASCIA, 1990, p. 52).

Na segunda parte, a crítica é toda voltada à ideologia do Partido Comunista, com 
suas contradições sempre incompreensíveis para Candido, porque "l'essere comunista era un fatto semplice come l'aver sete e voler bere; e non gli importava poi molto dei testi" (SCIASCIA, 1990, p. 75).

Mais tarde, expulso do Partido, Candido conhece sua prima Francesca e com ela viaja pelo mundo. Porém, se a Sicília e a Itália não vão bem, a Europa e o resto do mundo não estão melhores. Nas suas viagens à Espanha, eles veem o embaixador da China rendendo homenagens ao general Franco; no Egito, comunistas sendo presos diante de militares russos, e a América, por sua vez, devolvendo à Sicília uma legião de mafiosos com o propósito de assegurar o poder americano na ilha. Só em Paris, Candido e Francesca, contrariamente a Candide, não tiveram decepções, só ali eles andavam de mãos dadas e se sentiam felizes e livres. A viagem a Paris será definitiva, e representa uma peregrinação laica em contraposição àquela religiosa à Lourdes, feita por Candido e dom Antonio. Paris era para eles "una grande città piena di miti letterari, libertari e afrodisiaci che sconfinano l'uno nell'altro e si fondono [...]" (SCIASCIA, 1990, p. 120) e onde ainda era possível "mangiare e bere secondo letteratura" (SCIASCIA, 1990, p. 128). Esta é uma das grandes diferenças de Candide: em Candido a viagem se refere à literatura (reescritura).

A própria descrição de Paris, que aparece na ficção de Sciascia, pertence a um certo tenente austríaco Franz Tunda que, em 1926, se encontrava na França. As informações são do narrador que cita o texto entre aspas:

Davanti alle botteghe sostavano dei gatti, agitavano la coda come una bandiera. Stavano fermi con gli occhi che osservavano attenti, come cani da guardia davanti ai cesti d'insalata verde e di carote gialle, di cavoli dai riflessi bluastri e di rosati ravanelli. Le botteghe sembravano orti... Le terrazze dei caffè fiorivano di tavoli rotondi dalle gambe sottili, e i camerieri avevano l'aspetto di giardinieri, e quando versavano il caffè e il latte nelle tazze pareva annafiassero delle bianche aiuole. Lungo $i$ margini c'erano alberi e chioschi, pareva che gli alberi vendessero giornali. Nelle vetrine la merce danzava alla rinfusa, ma in un ordine ben preciso e sempre soprannaturale. Le guardie nelle strade andavano a passeggio, già, a passeggio, una pellegrina sulla spalla destra o sulla sinistra; che quell'indumento dovesse proteggere dalla grandine e da un acquazzone era ben strano. Tuttavia lo portavano con una fiducia 
incrollabile nella qualità della stoffa o nella bontà del cielo - chi può saperlo? Non giravano come guardie, ma come della gente che non ha da fare e ha tempo di vedersi il mondo. (SCIASCIA, 1990, p. 120).

Essa citação se encontra, na íntegra, num artigo intitulado "Parigi", publicado em Cruciverba (1983), coletânea de ensaios não datados, escritos em períodos diversos. Nele, Sciascia fala de suas impressões sobre a cidade e cita a descrição de Paris da década de 20, feita por um exilado austríaco, Joseph Roth, como sendo a mais próxima da imagem que ele, escritor, teve da capital francesa. Joseph Roth, por sua vez, no seu texto faz referências ao austríaco Tunda, como vemos na ficção sciasciana. No final das aspas, o narrador de Candido explica que: "Così come per il tenente Franz Tunda nel 1926 (austríaco, prima disperso dalla guerra in Siberia, poi dalla pace in Europa) era Parigi per Candido e Francesca mezzo secolo dopo" (SCIASCIA, 1990, p. 120).

Como se pode ver, a intertextualidade (a autotextualidade), ou seja, um texto inserido em outro texto adquirindo novos significados, é bastante explorada por Sciascia. As impressões do escritor (história) se transformam em impressões dos personagens (literatura), num diálogo contínuo entre textos.

O projeto de Candido de morar em Paris, terra de Voltaire, é um sonho realizado na ficção e pela ficção (já sonhado por Emma Bovary e tantos outros personagens literários). Francesca, grande conhecedora do idioma francês, propõe à editora Einaudi (a mais importante da Itália) a tradução (intertextualidade) de uma obra qualquer como prova de sua capacidade. Na tentativa de desencorajá-la da tarefa, a editora escolhe um texto difícil de Yves Bonnefoy, intitulado Un rêve fait à Mantoue. O significado do nome do autor Bonnefoy, buona fede [boa fé] é interpretado por Francesca como sinal de bom presságio, diversamente dos editores porque, segundo o narrador, "coloro che glielo davano da tradurre tanto in buona fede non erano" (SCIASCIA, 1990, p. 120).

A tradução, Un sogno fatto a Mantova, é aprovada pela editora e possibilita a mudança de Candido e Francesca para Paris, onde ela vai trabalhar como tradutora. Esse livro, em meio a outros que aparecem na obra, demonstra a sedução que a França exerce sobre a Sicília, e dá o significado à proposta de Candido. O narrador conta que Bonnefoy piaceva a tutti e due, quasi l'amavano. Un sogno fatto a Man- 
tova. Una sera che erano vicini a partire per Parigi e si sentivano come presi in un sogno, come dentro un sogno, Candido disse [a Francesca] Sai cos'è la nostra vita, la tua e la mia? Un sogno fatto in Sicilia. Forse siamo ancora lì e stiamo sognando. (SCIASCIA, 1990, p. 122).

Paris é um sonho, porque lá a vida se mistura à literatura e eles podem passear "nella mappa dei luoghi mitici parigini che in tanti anni di letture si era disegnata" (SCIASCIA, 1990, p. 127). A literatura como uma viagem: isto só é possível no éden dos livros, porque a literatura, a arte em geral, dá à utopia que todo poeta cultiva a possibilidade de existir por meio das palavras, das imagens. A literatura, a ficção, identificadas com o sonho, continuam sendo as melhores hortas que sempre podem ser cultivadas. Essa parece ser a proposta de Candido e talvez o limite ideológico de Sciascia.

Analisando as duas obras, constatamos que os personagens de Voltaire são apresentados como silhuetas, sem profundidade psicológica, servindo de alvos perfeitos para os ataques satíricos do autor contra: Leibniz (1646-1716) e a Metafísica; a religião católica com suas alianças políticas e militares; a nobreza decadente; o colonialismo e a escravidão; a guerra; o mito do bom selvagem; etc. Por meio desses personagens-marionetes, que funcionam como símbolos das suas ideias, Voltaire denuncia os preconceitos e a estupidez de sua época. Esses personagens extremamente contextuais não são retomados por Sciascia que, por sua vez, cria novos personagens, com outras finalidades.

Há em Candide cinco personagens que se opõem a Pangloss, cuja filosofia teórica - paródia da filosofia de Leibniz - consiste numa demonstração puramente mecânica, sem nenhuma lógica: "les nez ont été faits pour porter des lunettes; aussi avons-nous des lunettes" (VOLTAIRE, 1972, p. 17). Pangloss é um personagem que não evolui, insistindo até o fim que "tout était indispensable, [...] et les malheurs particuliers font le bien général; de sorte que plus il y a de malheurs particuliers, et plus tout est bien" (VOLTAIRE, 1972, p. 29).

Os opositores de Pangloss representam a sabedoria prática adquirida por meio do conhecimento e da experiência. O primeiro que se apresenta na narrativa de Voltaire é a velha que vai contar sua história "avec toute la prudence que l'âge et l'expérience 
donnent, [...]" (VOLTAIRE, p. 52). Ela será conselheira de Cunégonde porque, conforme suas palavras: "j'ai de l'expérience, je connais le monde" (VOLTAIRE, 1972, p. 50). O segundo, e mais radical, opositor de Pangloss é Martin que, conforme vimos anteriormente, personifica o pessimismo. O narrador conta que esse "pauvre savant avait travaillé dix ans pour les libraires à Amsterdan" (VOLTAIRE, p. 77), e está totalmente convencido de que "l'homme était né pour vivre dans les convulsions de l'inquiétude, ou dans la léthargie de l'ennui" (VOLTAIRE, 1972, p. 110). O terceiro personagem é o dervixe "qui passait pour le meilleur philosophe de la Turquie" (VOLTAIRE, 1972, p. 112) e que se nega a discutir sobre o bem e o mal com Pangloss, batendo-lhe com a porta na cara.

Os opositores restantes são outros dois velhos, também sem nomes: "un bon vieillard qui prenait le frais à sa porte sous un berceau d'orangers" (VOLTAIRE, 1972, p. 112), sem se importar com o que acontece no resto do mundo; um velhinho de 172 anos, "le plus savant homme du royaume, et le plus communicatif" (VOLTAIRE, 1972, p. 66) habitante do país do Eldorado; ele explica a Candide e a Cacambo que o reino do Eldorado, sem religião, sem rei, livre e feliz, era uma antiga terra dos Incas "qui nous a conservé notre innocence et notre felicite" (VOLTAIRE, 1972, p. 67).

Outros personagens voltairianos são:

- Jacques, "un homme qui n'avait point été baptisé, un bon anabaptiste" (VOLTAIRE, 1972, p. 26), que simboliza a tolerância e a caridade que os católicos não possuiam. Ele vai socorrer Candide depois que este é surrado por um pastor holandês;

- O nobre veneziano Pococurante, nom-portrait (poco curante, em italiano, significa indiferente), é um personagem cujo prazer consiste em não sentir prazer algum;

- Cacambo, companheiro de Candide, é um criado bastante experiente, que, com seus conhecimentos práticos e úteis, supera todas as dificuldades que os dois encontram durante as viagens;

- Vanderdendur, mais um nom-portrait (vendedor duro), é um terrível negociante holandês que corta a mão e a perna de seu escravo negro de Suriname, conforme l'usage (VOLTAIRE, 1972, p. 73). Naturalmente, Voltaire denuncia 
a prática da escravatura, principal consequência do Colonialismo:

- finalmente, por meio do negro do Suriname que nem nome tem, é mostrada a condição desumana em que os escravos vivem. A crítica a esse momento histórico é feita pelo próprio personagem que lamenta sua má sorte:

Les chiens, les singes et les perroquets sont mille fois moins malheureux que nous; les fétiches hollandais qui m'ont converti me disent tous les dimanches que nos sommes tous enfants d'Adam, blancs et noirs. Je ne suis pas généalogiste; mais si ces prêcheurs disent vrai, nous sommes tous cousins issus de germains. Or vous m'avouerez qu'on ne peut pas en user avec ses parents d'une manière plus horrible. (VOLTAIRE, 1972, p. 74).

Não é por acaso que a conversão total de Candide acontece diante da situação horrível em que esse escravo se encontra: “- O Pangloss! [...] tu n'avais pas deviné cette abomination; c'en est fait, il faudra qu'à la fin je renonce à ton optimisme" (VOLTAIRE, 1972, p. 74).

Ao contrário dos personagens voltairianos, os de Sciascia são mais caracterizados, isto é, estão mais próximos do referente real, são mais verossímeis, com exceção de Candido, cujo significado alegórico analisaremos mais adiante.

Cunégonde, por exemplo, é desdobrada na narrativa de Sciascia. Ela está representada por duas personagens: uma é Paola, mostrada por seus dotes físicos, com " $g l i$ occhi grigio-azzurri, una ciocca di capelli biondi, il taglio della bocca, la linea dal seno ai fianchi flessuosa [...]" (SCIASCIA, 1990, p. 72), corresponde ao amor juvenil e sensual do herói; a outra é Francesca, a prima de Candido que só aparece no final do conto (cap. XXII) e diz respeito ao amor da maturidade, mais espiritualizado. A relação com a primeira termina quando o amor de Paola se transforma em ideologia do amor. Apesar da perfeita harmonia de seus corpos, Paola vai embora porque não se sente merecedora do amor de Candido, "forse il corpo aveva ceduto all'anima" (p. 100), diz o narrador. Com Francesca a união é completa e duradoura. Ela é assim apresentada: "non si poteva dire bella, ma era negli occhi e nel sorriso luminosa. Intelligente, vivace, pronta alla battuta scherzosa e al giudizio tagliente" (SCIASCIA, 
1990, p. 113, grifamos).

Francesca, assim caracterizada, se aproxima da personalidade histórica de Voltaire, constituindo, a nosso ver, mais uma homenagem de Sciascia ao mestre francês (François(e)). Seu nome já significou 'habitante da França', sua habilidade com a língua francesa lhe permite realizar o sonho de Candido de viver em Paris e suas opiniões confortam-no sempre. Sobre os comunistas que expulsam Candido do Partido, considerando-o grande provocador, Francesca sugere: " $E$ se fossero soltanto degl'imbecilli?"'(SCIASCIA, 1990, p. 118).

Os personagens criados por Sciascia são:

- os pais de Candido, típicos representantes de uma burguesia falida moralmente: o pai, advogado Munafò "che aveva da provare l'innocenza di un assassino" (SCIASCIA, 1990, p. 20); a mãe Maria Grazia, esposa do lar e da Igreja, que, quando decide abandonar a família e anular seu casamento, procura agir "servendosi del partito de $i$ cattolici, dei preti, della Chiesa" (SCIASCIA, 1990, p. 20);

- o avô fascista, general Arturo, que agora é democrata cristão, "un uomo di potenti relazioni, per un passato che non era passato, e per un presente che somigliava al passato" (Sciascia, 1990, p. 105), representa a máxima gattopardesca de Lampedusa, segundo a qual tudo muda para que nada mude: "Se vogliamo che tutto rimanga come $\grave{e}$, bisogna che tutto cambi” (LAMPEDUSA, 1986, p. 21). E assim, quando Candido pergunta se ele havia errado no passado como fascista ou no presente como democrata, o avô enfurecido responde: "Ma che sbagliare, verme che sei! É la stessa cosa!" (SCIASCIA, 1990, p. 46, grifamos);

- Concetta Munasteri (monastero $=$ monastério), o nome fala por si, é uma personagem tirada das antigas comédias italianas. Solteirona, carola apaixonada por dom Antonio, Concetta é a governanta de Candido e responsável por sua educação na infância. Ela e dom Antonio simbolizam, respectivamente, os dois tipos de religião: a tradicional e a moderna;

- o advogado Paolo di Sales, um barão que tinha sido ajudante do general Arturo durante a guerra da Espanha, assume a função de secretário geral do Partido Comunista;

- Scalabrone, outro nom-portrait ((s)calabrone significa escaravelho que soterra 
excrementos; ou pessoa astuta), é o personagem que envia uma carta anônima ao general, denunciando o caso amoroso entre Paola e Candido. O narrador apresenta-o como "assiduo lettore del Boccaccio e non meno assiduo e sempre anonimo certificatore di illeciti sessuali e amministrativi" (SCIASCIA, 1990, p. 79), aludindo aos contos picantes e maliciosos do autor do Decameron.

- Há ainda um certo Zucco (zucca significa cabeça e zuccone, ignorante) que quer intermediar a venda de um terreno de Candido para a Prefeitura, não sem antes tirar algumas vantagens no negócio. O narrador explica que "il verbo sistemare [ajeitar, acertar] era da Zucco il prediletto" (Sciascia, 1990, p. 87);

- Fomàc Fomíc, por sua vez, é um personagem ficcional de "Fëdor Dostoevskij, Il villaggio di Stepàncikovo e i suoi abitanti, romanzo umoristico, 1859" (SCIASCIA, 1990, p. 92, grifo do autor), usado por Candido para chamar ironicamente um outro secretário do Partido Comunista quando este procura justificar, sem sucesso, a postura neutra do Partido diante da denúncia da tentatva de suborno realizada por Zucco: “Compagno, hai parlato come Fomà Fomíc" (SCIASCIA, 1990, p. 90).

Cada personagem de Sciascia, apesar de ser mais verossímel que o de Candide de Voltaire, também serve para criticar vários segmentos da sociedade, o seu modo de organização.

Quanto à construção da narrativa, sabemos que cada uma delas estabelece um acordo tácito com o leitor, que suspende sua crença para entrar no mundo da ficção. Na introdução de Candide, com "Il y avait en Westphalie, dans le château [...]" (VOLTAIRE, 1972, p. 17) fica previsto como leitor uma criança ou alguém que se comporte como tal, aceitando que o que vai se contar ultrapasse o razoável. Participando do jogo da ilusão, a própria questão da verossimilhança não se coloca mais e o inverossímil passa a ser a regra. Depois do era uma vez num castelo, tudo pode acontecer, e o efeito de sentido que tal protocolo de abertura instaura é o de pura fantasia, o maravilhoso dos contos de fada. Daí que Candide sobrevive a 4.000 chicotadas (VOLTAIRE, 1972, p. 22); Cunégonde (cap. III, IV) o barão (cap.XV), Pangloss e outros personagens morrem e ressuscitam; os carneiros são vermelhos e voam (VOLTAIRE, 1972, p. 65) e a própria criação do país do Eldorado é toda fantástica.

Na narrativa de Sciascia, o acordo é outro porque o narrador anuncia o nascimento 
do personagem em tempo, data e lugar situados historicamente, além de citar personagens históricos envolvidos na trama, criando um efeito de realidade analisado em outro momento (MAZZI, 2003, p. 39-56). Aqui a verdade dos fatos se impõe e o emprego de material realista é constante, como de resto acontece no realismo verghiano e no próprio neorrealismo.

O início das narrativas, portanto, constitui um ponto estratégico do texto uma vez que programa o seu modo de leitura, além de resolver uma tensão entre a informação e $\mathrm{o}$ interesse. Enquanto em Candide o narrador deve construir o mundo ficcional da narrativa, em Candido o leitor é introduzido, de imediato, em um universo realista ,com personagens nomeados ou socialmente marcados que correspondem ao nosso mundo.

Os estudiosos da narrativa, especialmente Genette, consideram a existência de dois grandes modos narrativos (diegesis e mimesis), que correspondem a duas tendências da narração (entendida como a organização da ficção na narrativa que a expõe). Embora toda história, em princípio, seja narrada no primeiro modo, diegesis. isto não é dissimulado e o narrador deixa ver as marcas de sua presença (narrador intruso). No segundo modo narrativo, o mimético, constrói-se a impressão de uma história sem mediador. Assim, enquanto os sumários predominam no modo de narrar, as cenas ocupam maior espaço no modo de mostrar, trazendo muitos diálogos "tais quais" eles surgem na história, ou seja, em discurso direto como em Candide. Em Candido, são explorados os sumários; por isso as falas dos personagens são narrativizadas, ou aparecem em forma de estilo indireto ou indireto livre. Na narrativa de Sciascia predomina o discurso indireto livre que representa os pensamentos dos personagens sem que o narrador precise abdicar de seu estatuto de mediador. Encontramos um bom exemplo quando o narrador fala da hostilidade dos camponeses e das ideias socialistas do protagonista:

Dell'odio dei contadini Candido, come abbiamo detto, non si accorgeva; ma il disagio di essere il padrone di quelle terre lo sentiva. Perché dovevano essere sue, tutte quelle terre? Com'è che un uomo - suo nonno o suo bisnonno - non lavorandole o lavorandone solo una minima parte le aveva fatte proprie? Ed era giusto riceverle come lui le aveva ricevute, e tenersele? (Sciascia, 1990, p.61). 
Ou, ainda, quando Zucco tenta em vão convencer Candido a negociar seu terreno:

"Ecco... Io... Mettiamo... Ecco..." Zucco era in difficoltà, non riusciva a trovare il giusto filo del discorso; del discorso da fare a uno sprovveduto, a un cretino come il giovane Munafò. Suo padre, buonanima avrebbe capito a volo. Suo nonno pure: pur non essendo intelligente e pur essendo onesto (una smorfia di disgusto si disegnò sulla faccia di Zucco, al pensiero dell'onestà del generale). Questo qui a chi assomigliava, di chi era figlio? (SCIASCIA, 1990, p. 88).

O discurso indireto livre, bastante explorado no romance do século XX, é um discurso híbrido em que a voz do personagem entra na estrutura formal do discurso do narrador, de modo a criar uma oscilação entre a voz de um e de outro. Porque proporciona uma confluência de vozes, o discurso indireto livre marca sempre a atitude do narrador em relação aos personagens. Em Sciascia a atitude é de distanciamento irônico e às vezes satírico em face deles, com exceção de Candido e de dom Antonio, nos quais a empatia é bastante acentuada, sobretudo em relação ao primeiro.

Como se sabe, as funções narrativa e de regência são próprias de todo narrador, mas o narrador em Candido assume outra função complementar importantíssima: a função metanarrativa que consiste em comentar o texto e em assimilar a sua organização. Ela é uma função de regência explícita que se presta a fins paródicos, como de resto faz Sciascia.

O narrador em Candido é heterodiegético porque está ausente como personagem, está fora da ficção e narra em $3^{\mathrm{a}}$ pessoa a partir do nível extradiegético. Ele assume a posição de autoridade incontestável em relação à história, conhece tudo e todos, manipula o tempo do discurso de forma desenvolta, remetendo o leitor ora para o futuro: "(si dice per dire, come poi vedremo)" (SCIASCIA, 1990, p. 18), "[...] diremo più avanti" (SCIASCIA, 1990, p. 59); ora para o passado: "come abbiamo detto" (Sciascia, 1990, p. 32), "abbiamo finora trascurato di dire" (SCIASCIA, 1990, p. 71); ora para o presente: "come noi la presentiamo" (SCIASCIA, 1990, p. 33), "possiamo dirlo noi" (SCIASCIA, 1990, p. 79), "compito cui siamo scarsamente adatti" (SCIASCIA, 
1990, p. 100) e "possiamo dire solo questo" (SCIASCIA, 1990, p. 100).

As intrusões do narrador são projetadas no enunciado pelos registros do discurso que traduzem juízos específicos sobre os acontecimentos e as atitudes dos personagens, muitas delas indicadas entre parênteses. Assim, em Candido a enunciação é enunciada. A enunciação é a instância linguística pressuposta pelo enunciado. Este pode apresentar ou não certos registros que remetem àquela. Segundo José Luiz Fiorin,

o processo enunciativo colocado no interior do enunciado não é a enunciação propriamente dita mas a enunciação enunciada. Teríamos, assim, dois conjuntos no texto-objeto: "a enunciação enunciada", que é o conjunto de marcas, identificáveis no texto, que remetem à instância de enunciação; e o "enunciado enunciado", que é a sequência enunciada desprovida de marcas de enunciação. (1996, p. 36).

As marcas do sujeito da enunciação no enunciado aparecem no discurso pessoal através do pronome elíptico de $1^{\text {a }}$ pessoa do plural, como nos exemplos acima citados. $\mathrm{O}$ narrador em Candide, que também é heterodiegético, se mostra na primeira pessoa do singular uma única vez no enunciado, quando, depois de caracterizar o protagonista, conclui: "[...] c'est, je crois, pour cette raison qu'on le nommait Candide" (VOLTAIRE, 1972, p. 17, grifamos).

Há registros do discurso modalizante marcados por advérbios e locuções adverbiais nos comentários do narrador: "sembrò una risposta sensata" (SCIASCIA, 1990, p. 13); "(che, per la verità trovava improbabile ci fosse)" (SCIASCIA, 1990, p. 33); "Candido candidamente diceva" (SCIASCIA, 1990, p. 44); "(tranne, si capisce, il generale Cressi e pochi altri)" (SCIASCIA, 1990, p. 46). Encontramos também discursos avaliativos formados por adjetivos: "insoportabile padrone da vivo" (SCIASCIA, 1990, p. 61) e outros.

Ao comentar os fatos, as ações e as reações dos personagens, o narrador se coloca do ponto de vista do leitor. $\mathrm{O}$ efeito desse procedimento é um certo distanciamento irônico que acaba chamando a atenção para o momento histórico que serve de fundo para a narrativa.

Além de registrar a presença da subjetividade no discurso (inerente à própria nar- 
rativa literária), as intrusões do narrador servem para dizer ao leitor que ele está diante de uma obra de ficção. Vale lembrar que toda técnica deve ser interpretada em seu contexto histórico. As intrusões do narrador, em séculos passados, contestavam as convenções e a recusa do realismo. Elas concorriam para criar o efeito de verossimilhança na narrativa. Hoje as intrusões contestam a vontade realista e chamam a atenção para o fazer do texto, para os mecanismos da escritura. $\mathrm{O}$ narrador dissimula sua presença dando a palavra às personagens que expressam suas opiniões, defendendo diferentes discursos como o da família, o da Igreja, o do Partido, e outros. Desse procedimento resulta uma narrativa polifônica construída sobre instâncias discursivas marcadas por formações ideológicas. O próprio conto filosófico por si só tem esse caráter fortemente dialogizado, dialético.

Quanto aos níveis narrativos, em Candido não temos as narrativas encaixadas ou chamadas mise em abyme, como a Histoire de Cunégonde (cap. VIII), a Histoire de la vieille (cap. XI) e a Suite des malheurs de la vieille (cap. XII) de Candide, em que o narrador dá voz e vez às personagens. Assim, Cunégonde e depois a velha assumem a narrativa, tornam-se narradores de uma ficção e transformam os demais personagens em leitores ouvintes. Como resultado, no nível da narração veremos alterada a ordem cronológica-lógica da narrativa. Essas perturbações temporais constituem anacronias por retrospecção (ou analepses) porque consistem em narrar mais tarde um acontecimento anterior. As analepses têm, em geral, uma função explicativa, como as de Candide, pois esclarecem o que cada personagem fez desde o seu desaparecimento. As anacronias narrativas por antecipação (ou prolepses) são as do tipo que aparecem em Candido, mas só algumas poucas vezes quando o narrador evoca um acontecimento posterior: "si dice per dire come poi vedremo" (p. 18).

Todo texto progride dosando cuidadosamente a repetição, responsável pela fixação da informação, e a novidade, que faz a história avançar. Trata-se da progressão temática que aparece na textualização do discurso, o nível mais visível da narrativa que materializa a ficção e a narração que o determinam. A progressão pode ser de tema constante como a de Candido, em que os vinte e seis capítulos discorrem sobre a história de Candido, ou de temas derivados como as citadas narrativas encaixadas de Candide, distribuídas entre 30 capítulos. A partir de um hipertema apresentado no 
início da narrativa - a vida de Candide e os demais habitantes do castelo - derivam subtemas quando alguns personagens contam a própria história, alterando, inclusive, a ordem de aparição dos acontecimentos.

Retomando o significado de Candide de Voltaire, vemos que este representa um caminho longo e difícil que vai da loucura fanática à razão. O personagem sai do castelo, o mundo da fantasia, e enfrenta o mundo "real", aprendendo a viver nele através do trabalho. Um significado intelectual antimetafísico de "Il faut cultiver notre jardin" sugere não perder tempo com problemas cujas soluções não dependem de atuações práticas. Outro significado social pode estar na apresentação do trabalho como elemento de valor: só ele torna a vida suportável.

Hoje, diante das preocupações e angústias do nosso tempo, uma afirmação como esta surge com conotações egoístas e burguesas. É preciso ressaltar que a lição do personagem Candide, concentrada na famosa frase, talvez a única dita em tom sério em toda a obra, só aparece no final do livro, não antes do trabalho ser apresentado como predestinação: “L'homme n'est pas né pour le repos”, diz Pangloss (p. 114).

As palavras de Italo Calvino acerca da referida frase, escritas na citada introdução ao livro de Voltaire, certamente ampliam e atualizam seu significado:

Non dobbiamo dimenticare il radicale cambiamento epistemologico ed etico che questa enunciazione segnava (siamo nel 1759, esattamente trent' anni prima della presa della Bastiglia): l' uomo giudicato non più nel suo rapporto con un bene e un male trascendenti ma in quel poco o tanto que può fare. E di lì derivano tanto una morale del lavoro strettamente produttivistica, nel senso capitalistico della parola, quanto una morale dell' impegno pratico responsabile concreto senza il quale non ci sono problemi generali che possano risolversi. Le vere scelte dell'uomo d'oggi, insomma, partono di lì. (CALVINO, 1995, p.10, grifo do autor).

Através da paródia, Sciascia cria um distanciamento em relação à verdade comum, o significado de "Il faut cultiver notre jardin", e opera a liberdade de outra verdade. No universo ficcional de Voltaire, Candide transcorre a vida num mundo de grandes fantasias, onde os personagens ultrapassam os limites do verossímil (alguns 
morrem e depois renascem várias vezes) para, no final, optarem por um porto seguro na "realidade": cada um cultivando a sua terra sem se preocupar com os demais, como ensina a ideologia burguesa. No universo ficcional de Sciascia, o caminho é inverso. A narrativa é ancorada em dados e situações do mundo "real", e Candido vive entre personagens históricos, mas não se adapta e se refugia no sonho, na ficção, na Paris literária. Enquanto Candide constrói a ilusão de ficcionalidade, Candido cria a ilusão de realidade. Sciascia retoma a forma original de Voltaire, esvazia seu conteúdo e coloca outro no lugar. Assim questiona a ideologia burguesa decorrente das relações entre a forma e o conteúdo do texto parodiado: através de Candido Sciascia coloca em dúvida, ou melhr, em discussão os valores tradicionais num processo de conscientização do ultrapassado no vigente. Por ser um discurso literário, uma ficção da ficção, a paródia questiona, denuncia, mas nunca dá respostas. $\mathrm{O}$ interesse do parodista é provocar a reflexão no leitor por meio da ironia e do humor, estratégias discursivas fundamentais que the permitem interpretar e avaliar. A ironia, que consiste em afirmar no enunciado e negar na enunciação, requer um enunciatário atento, com competência para decodificá-la. Quanto ao humor da paródia, ele está vinculado ao sério e provoca sempre a reflexão. Um humor pirandelliano que resulta do "sentimento do contrário", um humor sutíl que mescla o riso e o pranto. Segundo Pirandello, diante de uma situação, a simples constatação do oposto, do contrário, do inesperado, gera inicialmente o cômico. Mas a reflexão e, portanto, o sentimento deste produz o que ele chama de umorismo (1952). Mediante um narrador intruso, Sciascia provoca o leitor durante toda a narrativa, levando-o a refletir sobre o fazer literário e a própria História. Vejamos alguns exemplos. Quando o advogado Munafò descobre que, antes da guerra, o capitão das tropas aliadas era professor universitário de literatura italiana e filho de uma siciliana de uma aldeia vizinha, ele "enunciò a sua moglie la profonda verità [...]": "Il mondo è davvero piccolo", ao que o narrador completa, fazendo uma crítica à situação absurda gerada pela guerra: "Di questa opinione certamente non erano i soldati che in quel momento morivano a migliaia di chilometri dal loro paese [...]" (SCIASCIA, 1990, p. 16).

\section{Candido ou a metáfora da intertextualidade}


A paródia, por ser a ficção de uma ficção, apresenta o processo de produção do texto, desmistificando o discurso realista que criara a ilusão de referencialidade, isto é, a suposta ligação da narrativa com a realidade.

Candido de Sciascia questiona o modelo literário Candide, assim como este questiona o discurso filosófico do seu tempo, numa dinâmica dialética que leva o leitor a refletir sobre o momento presente. O texto de Sciascia está estruturado através da aceitação e réplica de vários discursos, constituindo-se numa obra altamente polifônica que usa o procedimento paródico como base de sua construção.

O título e o subtítulo de Sciascia antecipam o diálogo paródico, porque Candido, enquanto sonho, indica a transgressão, a inversão do "original" criando um significado ambivalente, isto é, duplo, uma escrita em que se lê o outro (Candide). Ora, no sonho, o mundo pode aparecer às avessas, carnavalizado, dialógico. Segundo Bella Josef, "o dialogismo da coexistência dos contrários, que Freud descobre no inconsciente do sonho, Bakhtin, coincidentemente chama de_lógica do sonho (JOSEF, 1980, p. 60, grifamos).

O diálogo intertextual em Candido se dá no entrecruzamento de textos históricos e literários, de épocas e autores do passado e do presente. No início deste capítulo. foram mostradas as referências explícitas a Voltaire e sua obra conduzindo o leitor para o reconhecimento da paródia.

A intertextualidade considerada na sua forma mais geral, ou seja, aquela manifestada nas referências culturais e artísticas que atravessam a obra, transparece em Sciascia de modo abundante nas citações e/ou alusões a várias personalidades políticas e literárias que fizeram história. Além de Voltaire que predomina na obra, há em Candido (SCIASCIA, 1990) referências diretas ou indiretas a tantos outros escritores como os italianos: Dante (p. 40), Pirandello (p. 51), Gramsci (p. 73-91), Machiavelli (p. 74), Manzoni (p.91) Boccaccio (p. 79), Togliatti (p. 86); os russos: Lênin, Marx e Gorki (p. 75), Dostoieviski (p. 92-93-103), Tolstoi (p. 103), Krachòthin (p. 94); os franceses: Bonaparte (p. 94), Stendhal (p. 70), Victor Hugo (p. 75-98), Zola (p. 75), Sartre (p. 131), Baudelaire (p. 120), Maillol (p. 132); os americanos: Hemingway e Fitzgerald (p. 
127); os ingleses: Shakespeare (p. 40), Dickens (p. 40); o austríaco Freud e o suiço Jung (p. 41). Todos os autores citados dialogam com Sciascia sendo que o significado de cada um deles para sua obra mereceria um estudo à parte. Cumpre precisar que todos eles fazem parte do saber erudito ou enciclopédico do narrador que tem total controle sobre a narrativa. Algumas personalidades são compartilhadas por Candido e dom Antonio, conforme indicamos no decorrer do trabalho, enquanto outras são referidas por personagens secundários, sem, entretanto, diminuir seu valor. Por exemplo, o secretário do Partido Comunista, que Candido chamou de Fomá Fomíc (o personagem de Dostoiévski) se sente vingado acusando-o de Tolstoi. Isto ocorre numa assembléia de partido, quando Candido insiste em doar suas propriedades para uma cooperativa agrícola: "E chi credi di essere, Tolstoj?" (SCIASCIA, 1990, p. 103), ele diz, numa clara alusão a sua condição de latifundiário que deseja a revolução.

Ao lado desse diálogo intertextual bastante diversificado, ocorre um diálogo intratextual, quer dizer, a paródia é produzida no interior do próprio discurso narrativo e é representada por Candido.

Considerando a paródia "um tipo de visão especular, em que a imagem 'original' se apresenta invertida, reduzida ou ampliada" (ARAGÃO, 1980, p. 21), temos, no início da narrativa sciasciana, a representação da mesma. O narrador conta que o advogado Francesco Maria, a caminho de casa, na noite do nascimento de seu filho, é atingido por uma explosão provocada pelos aliados que, naquele 9 de julho de 1943, invadem a Sicília. Após se recuperar do susto, ainda atordoado, o personagem encontra pela frente um pedaço de espelho trazido de alguma casa, pela explosão, e não se reconhece na imagem refletida. Diante da figura no espelho envolta num pó branco, Francesco Maria finalmente se vê como outro e compreende: "E così si rapprese in lui la coscienza di chi era, di dove era, di quel che era accaduto: attraverso quella parola. Candido, candido: il bianco di cui si sentiva incrostato, il senso di rinascere che cominciava a sgorgargli dentro" (SCIASCIA, 1990, p. 11, grifamos).

De volta para casa, Francesco Maria decide chamar de Candido o filho recém-nascido, com a aprovação da mulher, Maria Grazia, que vê no nome 
"una pagina bianca, [...] per scrivere vita nuova" (SCIASCIA, 1990, p. 10). Francesco Maria (versão italiana de François-Marie) é o modelo, no interior da obra, a partir do qual é criado Candido (paródia), assim como François-Marie Arouet (Voltaire) e sua criação Candide constituem o modelo para a paródia de Sciascia: Candido. "A paródia é normativa na sua identificação com o outro, mas é contestatária na sua necessidade edipiana de distinguir-se do outro anterior" (HUTCHEON, 1985, p. 98).

Essa ambivalência estabelecida entre repetição e diferença revolucionária faz parte da essência paradoxal da paródia. Candido, nascido da visão especular do pai, cresce contrariando física e ideologicamente todas as espectativas familiares e, aos cinco anos de idade, como já apontamos no capítulo anterior, é responsável por sua morte. Como a paródia, Candido recusa e esvazia o modelo original: seu pai.

Há, no interior do texto de Sciascia, a preocupação em discutir o próprio processo intertextual que já aparece na obra como um todo: Candido enquanto paródia de Candide. A cada situação vivida direta ou indiretamente pelo personagem, o narrador fala de outra semelhante, mas com diferença crítica (ora sutil, ora explicitamente irônica). Assim, ao contar que o nascimento de Candido foi assistido por muitas mulheres, o narrador interrompe a narrativa para dizer, entre parênteses, que a situação lembra a um dos presentes " ([ ...] quella della normanna Costanza che nella piazza di Jesi aveva messo al mondo l'imperator Federico, sotto una tenda e da tante donne circondato)" (SCIASCIA, 1990, p. 14). Trata-se de Frederico II, neto do legendário Barba-Roxa e filho de Henrique VI com a herdeira do reino normando da Sicília, conhecido como reformador extraordinário. Também Candido será responsável por grandes transformações.

Há um episódio em que Candido revela a confissão que ouvira às escondidas entre seu pai e um cliente assassino. A revelação feita ao coleguinha, filho do delegado encarregado do caso, provoca o suicídio do advogado e a condenação do réu a vinte e sete anos de prisão. O narrador compara o episódio verossímil com o verídico escândalo de Watergate ocorrido em 1974, que 
envolveu o então presidente dos Estados Unidos da América, Richard Nixon, provocando sua renúncia. Como resultado, temos um efeito de realidade criado no discurso ficcional, ao mesmo tempo em que o narrador critica duramente o personagem histórico:

Candido sapeva tutto di suo padre [...]. Lo sapeva così come i registratori del presidente Nixon sapevano tutto quello che il presidente Nixon diceva. Solo che Nixon sapeva dei registratori e l'avvocato Munafò non sapeva di Candido in ascolto: il che, agli effetti del disastro in cui entrambi incorsero, fa differenza per la costatazione che Munafò era meno imbecille di Nixon. (Sciascia, 1990, p. 28).

Se a paródia é por si só transgressora na medida em que transforma, por meio da inversão crítica, textos consagrados, então a transgressão se torna dupla quando se trata de textos sagrados. O intertexto bíblico aparece em Candi$d o$, em três momentos. No primeiro, quando Maria Grazia e Francesco Maria, já separados, simulam a disputa pela posse do filho, o narrador comenta: " $c i$ fosse stato un re Salomone, a decidere se al padre o alla madre Candido doveva essere affidato, forse il povero bambino sarebbe tagliato a metà: tanta era l'ostinazione che padre e madre mostravano nel volerlo" (SCIASCIA, 1990, p. 23). No segundo momento, o narrador compara ironicamente Francesco Maria com São José, na tentativa de justificar sua falta de amor por Candido, que se parece cada vez mais com seu rival, o capitão John Hamlet Dykes: "Che altro si poteva pretendere da un padre che si assomigliava [...] a Giuseppe figlio di Giacobbe la cui moglie per virtù dello Spirito Santo aveva concepito così come Maria Grazia per virtù dello Spirito Americano" (SCIASCIA, 1990, p. 27). Em um terceiro, a ocorrência do intertexto bíblico se dá quando dom Antonio é expulso da Igreja por ter desvendado, com a ajuda de Candido, o homicídio de um padre que engravidara uma paroquiana. Punido por ter defendido a verdade, que, segundo seu superior, às vezes deve ser omitida, diante dele dom Antonio desabafa parodiando a bíblia: "Io sono la via; la verità e la vita; ma a volte sono il vicolo cieco, la menzogna e la morte" (SCIASCIA, 1990, p. 57). 
Vale ressaltar um último exemplo em que os personagens Candido e dom Antonio discutem a questão da reescritura e se identificam com ela. Após um ano de vida em comum com Candido, Paola decide deixá-lo explicando, por meio de um bilhete, que levara consigo alguns objetos para recomeçar a vida longe dele. Ao comentar com dom Antonio que a amante esquecera de levar os castiçais de prata que tinham um certo valor comercial, o narrador remete ao pensamento do ex-padre, personagem que tem memória literária e vai se lembrar de uma obra lida em anos passados: "Dio mio, pensò don Antonio, come sono false le cose vere! Siamo a Monsignor Myriel, a Jean Valjean, ai Miserabili. O la nostra vita è ormai tutto ciò che è stato scritto...? Crediamo di vivere, di essere veri, e non siamo che la proiezione, l'ombra delle cose già scritte" (SCIASCIA, 1990, p. 98-9, grifamos).

Ao afirmar a falsidade das coisas verdadeiras o narrador compara as duas situações, a passada ficcional (representada pela obra Os Miseráveis, de Victor Hugo) com a presente como se fosse verdadeira (com o efeito de realidade que ela apresenta), para concluir que ambas são escrituras, ou melhor, reescrituras.

A tradução (da obra literária principalmente) é uma forma de intertextualidade cujo processo pressupõe, além das questões linguísticas e culturais, um trabalho de criação. A crítica moderna vê a tradução como reescritura. Ao ler a tradução de Francesca, uma ficção na ficção Un sogno fatto a Mantova, o próprio Candido conclui, parafraseando o título da obra, que a vida deles era un sogno fatto in Sicilia.

Como pudemos constatar, a vida de Candido segue o caminho inverso da linearidade cronológica dos acontecimentos: isso se verifica na súbita mudança do seu nome; na sua total indiferença à perda dos pais; no relacionamento com seu preceptor; na relação amorosa com a empregada Paola, amante do avô; no seu desprezo pelos bens materiais (contrariando uma tradição milenar entre os sicilianos) e em tantos outros exemplos que poderiam ser citados.

Os discursos e o comportamento de Candido são considerados excêntricos e inoportunos provocando sempre grandes reviravoltas. Por tudo isso, Candido pode ser lido como metáfora da paródia identificada com o conceito de car- 
navalização em Bakhtin, da intertextualidade, da literatura, da ficção. Enfim, enquanto o sonho do personagem Candido é viver $n a$ ficção (em Paris literária), o sonho do escritor Sciascia é viver $d a$ ficção (Candido). Esta é a consequência da ideologia de Sciascia e é também o limite histórico de suas reflexões que sugerem resolver tudo fora da história, na ficção.

Como diz Barthes, as forças da liberdade residem na literatura onde a língua é trapaceada, "essa trapaça salutar, essa esquiva, esse malogro magnífico que permite ouvir a língua fora do poder, no esplendor de uma revolução permanente da linguagem [...]" (BARTHES, 1977, p. 16, grifamos).

Tanto o personagem Candido quanto o escritor Sciascia escolhem a literatura afinal,

\begin{abstract}
a ficção é um lugar privilegiado: lugar em que o homem pode viver e contemplar, através de personagens variadas, a plenitude da sua condição, e em que se torna transparente a si mesmo; lugar em que, transformando-se imaginariamente no outro, vivendo outros papéis e destacando-se de si mesmo, verifica, realiza e vive a sua condição fundamental de ser autoconsciente e livre, capaz de desdobrar-se, distanciar-se de si mesmo e de objetivar a sua própria situação. [...]. Através da arte, disse Goethe, distanciamo-nos e ao mesmo tempo aproximamo-nos da realidade. (ROSENFELD, 1995, p. 49).
\end{abstract}

\title{
Referências bibliográficas:
}

ARAGÃO, M. L. P. A paródia em ‘A Força do destino'. In Tempo Brasileiro, 62, 1980.

BAKHTIN, M. La poétique de Dostoïevski. Paris: Seuil, 1970.

BARTHES, R. Aula. Trad. e Posfácio de Leyla Perrone-Moisés. São Paulo: Cultrix, 1977.

CALVINO, I. Il 'Candide' di Voltaire. In VOLTAIRE. Candido ovvero l'ottimismo. Trad. Piero Bianconi. Milano: Bur, 1995. p.5-11

CAMPI, R. Introduzione. In VOLTAIRE. Candido o l'ottimismo. Trad. Paolo Angioletti. Milano: T.E. Newton, 1994. p. 7-16

FACCHIN, L. Polifonia, carnavalização e paródia em Candide de Voltaire. In Revista de Letras. Unesp, 1995, p. 113-126. 
FIORIN, J. L. As astúcias da enunciação: as categorias de pessoa, espaço e tempo. São Paulo: Ática, 1996. (Ensaios, 144).

GENETTE, G. Palimpsestes: la littérature au second degré. Paris: Seuil, 1982.

HUTCHEON, L. Uma teoria da paródia. Lisboa - Rio: Edições 70, 1985.

JOSEF, B. O espaço da paródia. Rio: Tempo Brasileiro, 1980. p. 53-70

LUPERINI, R. Il novecento. T. 2. Torino: Loescher Ed., 1981.

MAZZI, M. G. C. Fato \& ficção em Candido de Leonardo Sciascia. In Italianística. São Paulo: EDUSP, 2003. p. 39-56

MOISÉS, M. A criação literária: introdução à problemática da literatura. São Paulo: Melhoramentos - Edusp, 1975.

PETIT LAROUSSE ILLUSTRË. Paris: Liv. Larousse, 1982.

PIRANDELLO, L. L'Umorismo. In . Saggi. Verona: Mondadori, 1952.p. 13-176

ROSENFELD, A. Literatura e Personagem. In CANDIDO, A. A personagem de ficção. São Paulo: Ed. Perspectiva, 1995. p. 11-49

SARTRE, J. P. Huis clous- Les Mouches. Paris: Gallimard, 1966.

SCIASCIA, L. Todo Modo. Torino: Einaudi, 1974.

Candido ovvero Un sogno fatto in Sicilia. Milano: Adelphi Edizioni, 1990.

VOLTAIRE. Candide ou l'optimisme. Présenté par Paul Vernière. Paris: Didier, 1972. 